\title{
Long-term outcome and quality of life of patients with unstable pelvic fractures treated by closed reduction and percutaneous fixation
}

\author{
Kapalı redüksiyon ve perkütan vidalama ile tespit edilmiş anstabil pelvis kırıklı \\ hastalarda yaşam kalitesinin ve uzun dönem sonuçların değerlendirilmesi
}

\author{
Mehmet AYVAZ, ${ }^{1}$ Ömür ÇAĞLAR, ${ }^{1}$ Güney YILMAZ, ${ }^{1}$ Gizem İrem GÜVENDİK, ${ }^{2}$ \\ Rıfat Emre ACAROĞLU ${ }^{1}$
}

\section{BACKGROUND}

Treatment of unstable pelvic fractures has evolved recently, and percutaneous treatment has become the choice of treatment in most cases. The aim of this study was to evaluate the outcome of percutaneous treatment in patients with unstable pelvic fractures.

\section{METHODS}

Twenty patients ( 11 females, 9 males; mean age, 32 years, range, 11-66 years) who had unstable pelvic fractures and were treated percutaneously were enrolled in the study. Short Form-36 (SF-36) scores, Majeed scores, Iowa Pelvic Scores, and Pelvic Outcome Scores were determined for the outcome assessment.

\section{RESULTS}

The minimum duration of follow-up was 2 years, (range, 24-48 months). The mean Injury Severity Score (ISS) was 31 (range, 16-50). The average SF-36 scores were comparable with the general population in terms of bodily pain, general health and social function. The mean Majeed functional pelvic score was 93.3 (range, 72-100; 19 excellent and 1 good clinical grades) and the mean Iowa Pelvic Score was 86 (range, 82-90). The mean Pelvic Outcome Score was 33 (range, 24-37; maximum score, 40).

\section{CONCLUSION}

We have demonstrated better outcomes in patients with pelvic fractures treated with percutaneous fixation. The technique may be advantageous as it avoids the use of extensive approaches, bleeding, wound complications, and prolonged surgeries.

Key Words: Pelvic fracture; percutaneous treatment; outcome.

\section{$\boldsymbol{A M A C}$}

Kapalı redüksiyon ve perkütan vidalama ile tespiti son zamanlarda pelvis kırıklı hastaların çoğunda tedavi seçeneği olmuştur. Bu çalışmanın amacı, anstabil pelvis kırık11 hastalarda uygulanan perkütan tedavinin uzun dönem sonuçlarının ve hastaların yaşam kalitesinin değerlendirilmesidir.

\section{GEREÇ VE YÖNTEM}

Ortalama yaşı 32 (dağılım 11-66 yaş) olan 20 hasta (11 kadın, 9 erkek) çalışmaya dahil edildi. Sonuçların ve yaşam kalitesinin değerlendirilmesi macıyla Kisa Form-36 (KF36) anketi, Majeed skorlaması, Iowa pelvik skorlaması ve pelvik sonuç değerlendirme skorlaması kullanıldı.

\section{BULGULAR}

En kısa takip süresi 2 yıl (dağılım 2-4 y1l) idi. Ortalama yaralanma şiddet skoru 31 (dağılım 16-50) olarak bulundu. Ortalama KF-36 skorları vücut ağrısı, genel sağlık ve sosyal fonksiyonlarda normal toplum değerleri ile benzer bulundu. Ortalama Majeed skoru 93.3 (dağılım 72-100; 19 mükemmel ve 1 iyi klinik sonuç) ve ortalama Iowa pelvik skoru 86 (dağılım 82-90) olarak bulundu. Ortalama pelvik sonuç değerlendirme skoru ise 33 (dağılım 24-37; en yüksek olası skor, 40) idi.

\section{SONUC}

Pelvis kırıklarında perkütan tedavi yöntemi ile iyi sonuçlar elde etmek mümkündür. Geniş cerrahi yaklaşımların önlenmesi, kanamanın, yara problemlerinin az olması ve uzun süreli cerrahilerden kaçınılması tekniğin avantajlaridir.

Anahtar Sözcükler: Pelvis kırıkları; perkütan tedavi; sonuç.

\footnotetext{
${ }^{1}$ Department of Orthopedics and Traumatology, Hacettepe University Faculty of Medicine, Ankara;

${ }^{2}$ Hacettepe University, School of Physiotheraphy, Ankara, Turkey.
}

${ }^{1}$ Hacettepe Üniversitesi Tıp Fakültesi, Ortopedi ve Travmatoloji Anabilim Dalı, Ankara; ${ }^{2}$ Hacettepe Üniversitesi Fizyoterapi Okulu, Ankara. 
Despite the fact that unstable pelvic fractures are the most serious orthopedic injury, controversy exists regarding the recommended treatment and outcome. [1-12] The outcome of these fractures is dependent on anatomic reduction and stabilization. Early anatomic reduction and stable fixation of the unstable pelvis have been shown to diminish pain, allow early mobilization and improve patient outcome. ${ }^{[1-5]}$

Open reduction and internal fixation of pelvic ring disruptions were routinely delayed to avoid entering the pelvic hematoma and thereby causing additional hemorrhage. The techniques of closed reduction and percutaneous pelvic fixation can be used for early stabilization of unstable anterior and posterior pelvic fractures and provide stable internal fixation, while avoiding large surgical exposure, derangement of hematomas and potential complications associated with these major surgeries. ${ }^{[8-12]}$ Percutaneous fixation is thought to improve the outcome of unstable pelvic injuries; however, to our knowledge, no studies have yet demonstrated the long-term functional outcome and quality of life of patients with these injuries.

The aim of the present study was to evaluate the long-term functional outcome and quality of life of patients with unstable pelvic fractures who were treated with closed reduction and percutaneous fixation.

\section{MATERIALS AND METHODS}

In the present study, 32 patients with pelvic fractures treated in our institution between August 2004 and August 2006 by one surgeon (EA) were evaluated retrospectively. Patients with unstable pelvic fractures who were treated with closed reduction and percutaneous fixation with at least 2 years of followup were included in the study. The patients treated with conservative or open methods and those with $<2$ years of follow-up were excluded. A total of 20 patients ( 11 females, 9 males) who fulfilled the inclusion criteria were enrolled in the study. Two patients were excluded ( 1 patient died in the postoperative 2nd week due to multiorgan failure and nosocomial sepsis, and 1 patient died in the postoperative 11th month following a myocardial infarction). Hospital charts, pre- and postoperative posteroanterior, inlet and outlet pelvic X-rays and computed tomography scans were evaluated.

There were 9 male and 11 female patients, with an average age of 32 years (range, 11-66 years) at the time of injury. All of the injuries were related to motor vehicle accidents or pedestrian-vehicular collisions. Fractures were classified according to Young and Burgess $^{[13]}$ (Table 1), and the Injury Severity Scores (ISSs) were calculated.

All of the operations were performed under general anesthesia in the supine position. A radiolucent operating table and conventional fluoroscopy were used. The initial step was closed reduction of the fracture with the aid of traction or an external fixator. For the placement of iliosacral screws, a guidewire was passed from the lateral edge of the ilium, perpendicular to the sacroiliac joint, towards the body of the first sacral vertebra. The pelvic inlet and outlet views and lateral views of the sacrum were obtained to confirm the correct positioning of the guidewire within the safe zone. A $7.3 \mathrm{~mm}$ (Kanghui medical) or $6.5 \mathrm{~mm}$ (Smith and Nephew) cannulated screw was then placed perpendicular to the sacroiliac joint. Longer screws were used for fixation of sacral fractures. Following placement of the first screw, a second screw was used when needed. For retrograde placement of the superior pubic ramus screw, an incision, $1 \mathrm{~cm}$ in length, was performed inferior and lateral to the ipsilateral pubic tubercle. A guidewire was passed at a $45^{\circ}$ angle from medial-to-lateral through the superior pubic ramus across the fracture and above and anterior to the hip. Obturator-outlet and iliac-inlet views were used to check the correct position of the screw. Then, a 7.3 $\mathrm{mm}$ or $6.5 \mathrm{~mm}$ cannulated screw was used for fixation.

A general health survey (Short Form-36 [SF-36]), commonly used to assess the overall outcome in orthopedic injuries, was used. Orthopedic outcome tools (Majeed score, ${ }^{[14]}$ Iowa Pelvic Score [IPS], and Pelvic Outcome Score) were also used to determine patient

Table 1. Young and Burgess classification

\begin{tabular}{|c|c|c|c|}
\hline Mechanism and Type & Characteristics & Displacement & Stability \\
\hline AP compression, type I & Pubic diastasis $<2.5 \mathrm{~cm}$ & External rotation & Stable \\
\hline AP compression, type II & Pubic diastasis $>2.5 \mathrm{~cm}$, anterior SI joint disruption & External rotation & Rotationally unstable, vertically stable \\
\hline AP compression, type III & Type II plus posterior SI joint disruption & External rotation & Rotationally unstable, vertically unstable \\
\hline Lateral compression, type I & $\begin{array}{l}\text { Ipsilateral sacral buckle fractures, ipsilateral horizontal } \\
\text { pubic rami fractures (or disruption of symphysis with } \\
\text { overlapping pubic bones) }\end{array}$ & Internal rotation & Stable \\
\hline Lateral compression, type II & Type I plus ipsilateral iliac wing fracture or posterior & & \\
\hline & SI joint disruption & Internal rotation & Rotationally unstable, vertically stable \\
\hline Vertical shear & $\begin{array}{l}\text { Vertical pubic rami fractures, SI joint disruption } \\
\pm \text { adjacent fractures }\end{array}$ & Vertical & Rotationally unstable, vertically unstable \\
\hline
\end{tabular}

AP: Anteroposterior; SI: Sacroiliac. 
outcome. All of the surveys and tools were applied by an independent observer via personal interviews, except for the Pelvic Outcome Score, which evaluates the radiographs for residual displacement. The SF-36 is a general health assessment tool constructed to provide a broad measurement of health and has been vali-
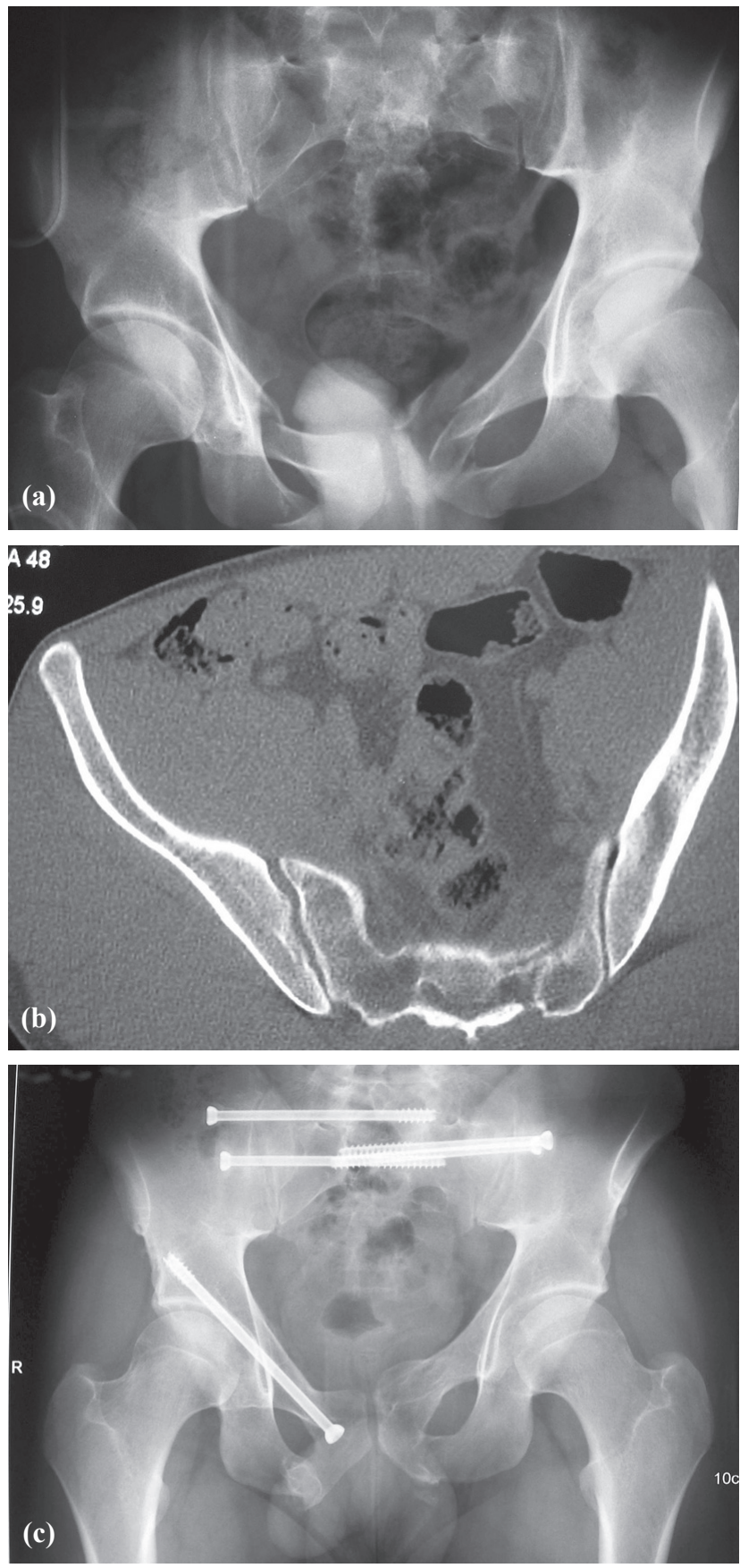

Fig. 1. (a) Anteroposterior pelvic X-ray of a 21-year-old man with unstable pelvic fracture. (b) Computed tomography section showing posterior injury. (c) Anteroposterior pelvic X-ray three years after percutaneous treatment of the fracture. The Majeed radiographic score was excellent. The Iowa Pelvic Score was 87 points (excellent). The physical function score of SF-36 was 94.4. dated and shown to be reliable for the Turkish population. ${ }^{[15]}$ The survey was administered by means of a personal interview or telephone conversation. Each scale is evaluated with a range score of 0 to 100 , and can be compared with an age- and gender-matched set of normal values.
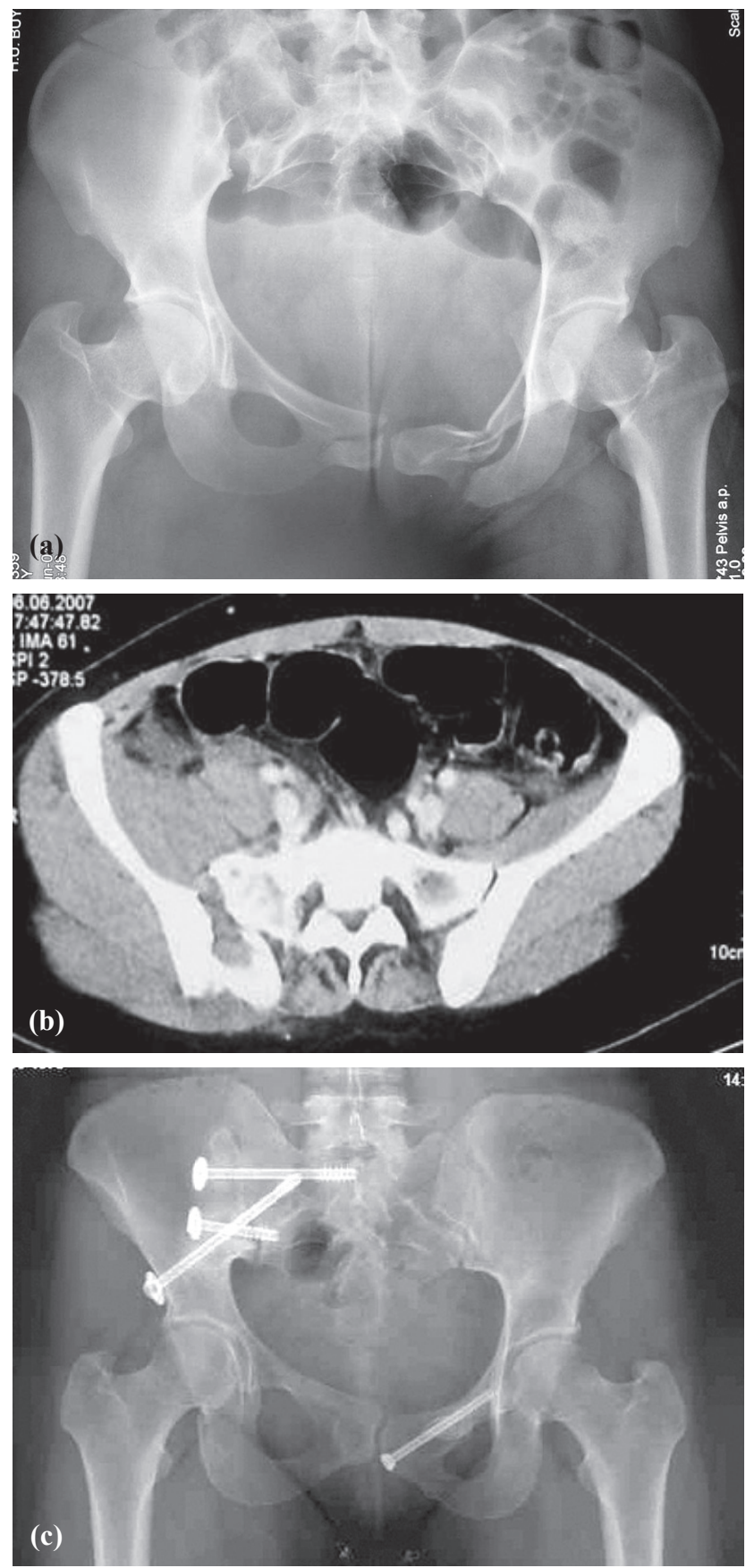

Fig. 2. (a) Anteroposterior pelvic X-ray of a 39-year-old woman with unstable pelvic fracture. (b) Computed tomography section showing posterior injury. (c) Anteroposterior pelvic X-ray two years after percutaneous treatment of the fracture. The Majeed radiographic score was excellent. The Iowa Pelvic Score was 90 points (excellent). The physical function score of SF-36 was 100. 
The Majeed score is a pelvic injury-specific functional assessment divided into the following seven items: pain, work, sitting, sexual intercourse, standing, unaided gait, and walking distance. ${ }^{[14]}$ The IPS is also a pelvic injury-specific assessment divided into the following 6 items: daily living activities (20 points), work history (20 points), pain ( 25 points), limping ( 20 points), visual pain line (10 points), and cosmesis (5 points) ${ }^{[16]}$ Each of the total Majeed scores and IPSs range from 0-100; higher scores represent decrease in disability.

A 40-point Pelvic Outcome Score is used to assess the following items: pain, ambulation, work and activity status, clinical examination, and radiographs. ${ }^{[6]}$ Postoperative anteroposterior and inlet and outlet views of the pelvis were used to determine a radiographic score based on the presence of healing, reactive changes or fusion at the sacroiliac joint and the degree of anterior or posterior displacement.

\section{RESULTS}

The minimum follow-up was 2 years, with a mean duration of follow-up of 33.3 months (range, 24-52 months). The mean ISS was 31 (range, 16-50). Five patients had anteroposterior compression type III (APC-III), 3 patients had APC-II, 3 patients had lateral compression type II (LC-II), 4 patients had LCIII, 4 patients had vertical shear (VS) injuries, and 2 patients had combined mechanism (CM) injuries. The mean delay of surgery was 3 days (range, 0-7 days). Iliosacral screws were used in all patients for posterior fixation, and for anterior fixation, retrograde pubic ramus screws were used in 11 patients and external fixators in 6 patients. Screws were applied in the supine position and under fluoroscopic guidance. One pubic ramus screw was removed because of an intraarticular placement and another screw was removed due to a superficial infection. One iliosacral screw was changed for treatment of pseudoarthrosis. There were no fixation failures or neurovascular complications. The radiographs of two patients are shown in Figures 1 and 2 .

The associated injuries were as follows: chest injuries (pneumothorax, hemothorax, rib fractures, lung contusions) in 5 patients; cervical spine injuries in 2 patients; thoracic spine injury in 1 patient; lumbar spine injuries in 2 patients; lower extremity fractures in 9 patients; upper extremity fractures in 2 patients; head injuries (skull fractures, subdural and subarachnoid hematomas); hepatic injuries in 2 patients; splenic injury in 1 patient; sigmoid rupture in 1 patient; and urethral injuries in 2 patients. Two patients with sacral fractures had cauda equina lesions pre-operatively that resolved within 6 months after stabilization.

The average Majeed score was 93.3 (range, 72-
$100 ; 19$ excellent and 1 good clinical grades). The average IPS was 86 (range, 82-90). There were 11 patients with an excellent IPS, and 9 patients with a good IPS according to Nepola et al. ${ }^{[16]}$ The average Pelvic Outcome Score was 33 (24-37).

The average SF-36 scores were comparable with the general population in terms of bodily pain, general health and social function scores, which were 3.3, 4.4, and 7.9, respectively. Similar to the general population, the average physical component score of the SF36 was 81.3 (range, 22.5-100), and the average mental component score of the SF-36 was 80.8 (range, 33.3100).

Fourteen patients who were working before the injury had returned to their current full-time jobs at the time of the final follow-up evaluation; of those, only 1 patient working as a salesman had to change his job.

\section{DISCUSSION}

In the present study, we have reported the longterm outcome of patients with unstable pelvic fractures treated with closed reduction and percutaneous fixation. The average Majeed score, IPS and Pelvic Outcome Score of the patients were 93.3, 86, and 33, respectively. The average scores of all components of the SF-36 were comparable with the normal population, and $92 \%$ of the working patients returned to their full-time jobs after treatment.

The ideal treatment for unstable pelvic fractures remains a matter of debate. The main purpose of the treatment for these serious injuries is to save the patient's life and then to achieve an excellent functional outcome.

Several operative and non-operative treatment options have been suggested for acute management of severe pelvic disruption. External fixation has been previously recommended for the early emergent stabilization of unstable pelvic ring disruptions to aid in hemodynamic resuscitation; ${ }^{[17]}$ however, the use of external fixation as a definitive means of stabilization in patients with posterior injuries is still questioned because of its mechanical inability to maintain reduction. Current treatment approaches emphasize the need for early anatomic restoration and internal fixation to maintain reduction and to improve the functional outcome of these patients.

Open reduction and internal fixation of pelvic ring disruptions are routinely delayed to avoid entering the pelvic hematoma, thereby causing additional hemorrhage with an increased risk of mortality. Delayed operative intervention allows maturation of the hematoma, but diminishes the success of closed manipulative reduction. However, open reduction and internal fixation of posterior pelvic injuries, in particular, are 
associated with a high rate of wound complications. ${ }^{[18]}$

Closed reduction and percutaneous fixation can be urgently performed, even during the initial resuscitation of the patient, thereby diminishing pelvic bleeding. Percutaneous pelvic ring fixation using fluoroscopic guidance provides stability. Stable percutaneous pelvic fixation also decreases operative blood loss and time, is associated with a very low wound complication rate, and allows comfortable mobilization of the patient. Accurate closed reduction of pelvic ring disruption is necessary before percutaneous fixation, and is best accomplished before maturation of the pelvic hematoma and deformity. Percutaneous pelvic fixation does not decompress the pelvic hematoma; thus, early surgical stabilization would be possible without the risk of additional hemorrhage, thereby allowing improved patient comfort, mobility and healing. Although these advantages of closed reduction and percutaneous fixation are well known, to our knowledge there is no published data on the quality of life and functional outcome of patients treated in this manner.

The outcome of operatively-treated pelvic fractures has been examined, and many authors have reported that average SF-36 scores were impaired in $\leq 55 \%$ of the patients, and $\leq 35 \%$ of the patients could not return to their current jobs. ${ }^{[6,19-25]}$ The associated injuries alter the long-term outcome of patients with unstable pelvic injuries. ${ }^{[6,19,20]}$ Neurologic injuries have been reported to have a detrimental effect on outcomes. ${ }^{[20]}$ The lack of long-term follow-up, uniformity in initial treatment and experience of the surgeon in this field are other problems when evaluating the long-term functional outcomes. ${ }^{[6]}$

The better findings of the present study regarding the functional outcome of patients may be attributed to the lower percentages of neurologic injuries $(10 \%)$ compared to studies reported previously $(\leq 38 \%)$. ${ }^{[20]}$ Another reason for the discrepancy in findings may be the relatively longer patient follow-up. It has been reported previously that patients with longer than 1 year of follow-up had better outcomes. ${ }^{[6]}$ In addition to the longer follow-up duration, uniformity of the treatment protocol and application of the procedures by the same surgeon may be regarded as the strengths of the present study. On the other hand, the retrospective design, lack of a control group, small sample size, and presence of heterogeneous injuries were the limitations of the study.

Percutaneous treatment is suggested in the treatment of unstable pelvic fractures as it avoids the use of extensive approaches, bleeding, wound complications, and prolonged surgeries. Better outcomes can be achieved in the long-term follow-up. Further studies with larger sample sizes are needed.

\section{REFERENCES}

1. Goldstein A, Phillips T, Sclafani SJ, Scalea T, Duncan A, Goldstein J, et al. Early open reduction and internal fixation of the disrupted pelvic ring. J Trauma 1986;26:325-33.

2. Matta JM, Saucedo T. Internal fixation of pelvic ring fractures. Clin Orthop Relat Res 1989;242:83-97.

3. Riemer BL, Butterfield SL, Diamond DL, Young JC, Raves JJ, Cottington E, et al. Acute mortality associated with injuries to the pelvic ring: the role of early patient mobilization and external fixation. J Trauma 1993;35:671-7.

4. Dujardin FH, Hossenbaccus M, Duparc F, Biga N, Thomine JM. Long-term functional prognosis of posterior injuries in high-energy pelvic disruption. J Orthop Trauma 1998; $12: 145-51$.

5. Latenser BA, Gentilello LM, Tarver AA, Thalgott JS, Batdorf JW. Improved outcome with early fixation of skeletally unstable pelvic fractures. J Trauma 1991;31:28-31.

6. Cole JD, Blum DA, Ansel LJ. Outcome after fixation of unstable posterior pelvic ring injuries. Clin Orthop Relat Res 1996;329:160-79.

7. Kellam JF, McMurtry RY, Paley D, Tile M. The unstable pelvic fracture. Operative treatment. Orthop Clin North Am 1987; 18:25-41.

8. Routt ML Jr, Kregor PJ, Simonian PT, Mayo KA. Early results of percutaneous iliosacral screws placed with the patient in the supine position. J Orthop Trauma 1995;9:207-14.

9. Routt M. Supine positioning for the placement of percutaneous sacral screws in complex posterior pelvic ring trauma. Orthop Trans 1992;16:220.

10. Giannoudis PV, Tzioupis CC, Pape HC, Roberts CS. Percutaneous fixation of the pelvic ring: an update. J Bone Joint Surg [Br] 2007;89:145-54.

11. Shuler TE, Boone DC, Gruen GS, Peitzman AB. Percutaneous iliosacral screw fixation: early treatment for unstable posterior pelvic ring disruptions. J Trauma 1995;38:453-8.

12. Ebraheim NA, Rusin JJ, Coombs RJ, Jackson WT, Holiday B. Percutaneous computed-tomography-stabilization of pelvic fractures: preliminary report. J Orthop Trauma 1987;1:197-204.

13. Young JW, Burgess AR, Brumback RJ, Poka A. Pelvic fractures: value of plain radiography in early assessment and management. Radiology 1986;160:445-51.

14. Majeed SA. Grading the outcome of pelvic fractures. J Bone Joint Surg [Br] 1989;71B:304-306.

15. Demiral Y, Ergor G, Unal B, Semin S, Akvardar Y, Kivircik $\mathrm{B}$, et al. Normative data and discriminative properties of short form 36 (SF-36) in Turkish urban population. BMC Public Health 2006;6:247.

16. Nepola JV, Trenhaile SW, Miranda MA, Butterfield SL, Fredericks DC, Riemer BL. Vertical shear injuries: is there a relationship between residual displacement and functional outcome? J Trauma 1999;46:1024-30.

17. Kellam JF. The role of external fixation in pelvic disruptions. Clin Orthop Relat Res 1989;241:66-82.

18. Kellam JF, McMurtry RY, Paley D, Tile M. The unstable pelvic fracture. Operative treatment. Orthop Clin North Am 1987; 18:25-41.

19. Kabak S, Halici M, Tuncel M, Avsarogullari L, Baktir A, Basturk M. Functional outcome of open reduction and internal fixation for completely unstable pelvic ring fractures (type C): a report of 40 cases. J Orthop Trauma 2003;17:55562.

20. Suzuki T, Shindo M, Soma K, Minehara H, Nakamura K, 
Uchino $\mathrm{M}$, et al. Long-term functional outcome after unstable pelvic ring fracture. J Trauma 2007;63:884-8.

21. Oliver CW, Twaddle B, Agel J, Routt ML Jr. Outcome after pelvic ring fractures: evaluation using the medical outcomes short form SF-36. Injury 1996;27:635-41.

22. Van den Bosch EW, Van der Kleyn R, Hogervorst M, Van Vugt AB. Functional outcome of internal fixation for pelvic ring fractures. J Trauma 1999;47:365-71.

23. Tornetta P 3rd, Matta JM. Outcome of operatively treated unstable posterior pelvic ring disruptions. Clin Orthop Relat Res 1996;329:186-93.

24. Pohlemann T, Gänsslen A, Schellwald O, Culemann U, Tscherne $\mathrm{H}$. Outcome after pelvic ring injuries. Injury 1996;27:B31-8.

25. Gruen GS, Leit ME, Gruen RJ, Garrison HG, Auble TE, Peitzman AB. Functional outcome of patients with unstable pelvic ring fractures stabilized with open reduction and internal fixation. J Trauma 1995;39:838-45. 